\title{
New uses for old urine tests
}

The human kidneys generate $130 \mathrm{ml}$ of plasma ultrafiltrate a minute. It is concentrated by the tubular portion of the nephron so that $1 \mathrm{ml}$ of urine reaches the bladder. If no concentration took place the extracellular water $\left(\begin{array}{ll}12 & 1\end{array}\right)$ would be lost in $1.5 \mathrm{~h}$ and the whole body water (41 1) in $5 \cdot 2 \mathrm{~h}$. It is no wonder that the earliest renal function tests dealt with the concentration capacity of the kidneys or with the clearance of endogenous substances, such as creatinine, or of exogenous markers, such as hippuric acid. Although powerful diagnostic aids in manifest renal disease, they may be less amenable to the early detection of subclinical kidney dysfunction. Their accurate application also necessitates visits to outpatient clinics or special laboratories.

Increased concern about the toxic aetiology of chronic renal dysfunction has been raised in some recent epidemiological surveys. ${ }^{1-3}$ At the same time, the understanding of nephrotoxicology has greatly advanced ${ }^{4}$ allowing the application of toxic mechanism orientated spot tests of urine. Although mostly designed to detect renal damage by chemicals, they may also prove useful in infectious, diabetic, or ischaemic diseases.

The selection of these spot tests is mostly made on the basis that they probe the integrity of the glomerular filtration apparatus or aspects of tubular functions that are not much affected by the hydration status of the body. For example, the spot tests may include a direct demonstration of deformed erythrocytes of glomerular origin or of nephron segment specific macromolecules.

\section{Electrolytes}

The resorption of sodium, potassium, and chloride serves as the basis of the water retention. ${ }^{6} \mathrm{~A}$ recent hypothesis holds that the renin secretion that activates the angiotensin aldosterone system might, in fact, be regulated by chloride ions rather than by sodium. ${ }^{6}$ This suggests that chloride channel blockers should lead to natriuria and kaliuria because of the necessary electric neutrality of the urine and this does seem to be the case. Phenoxyacid herbicides are blockers of muscle chloride channel which may partially explain the myotonic syndrome in herbicide poisoning. ${ }^{7}$ Such extremes are not seen in non-accidental exposure to these agents, possibly because of their high plasma protein binding which restricts their bioavailability. Nevertheless, 2,4,5-trichlorophenoxyacetate causes natriuria in rats ${ }^{8}$ and in occupationally exposed men causes comparable time and dose dependent excretion of sodium and potassium ions. ${ }^{9}$

Over $80 \%$ of absorbed phenoxyacids are excreted as such in urine. The mechanism by which the association with their protein carrier is dissolved is not known. The dissolution, however, creates concentrations in the renal parenchyma high enough to cause significant effects on the reabsorption of these ions. The peak of the natriuretic and kaliuretic effect of these herbicides in the sprayers preceded the peak phenoxy acid concentrations in the urine by some hours. ${ }^{9}$ This may indicate that the wash out of the agents from the tubular segments is a slow process. It also raises the question of how the agents are eliminated or whether they associate only with the luminal end of the chloride channel. Whatever the mechanism, the excessive loss of electrolytes explains well the hypotensive crises seen in human poisoning. ${ }^{10-12}$

Calcium ions have a tubular reabsorption maximum $(\mathrm{TmCa})$ that is bimodally distributed in healthy subjects. ${ }^{13}$ The TmCa of controls is negatively correlated with urinary sodium, ${ }^{13}$ possibly because part of the $\mathrm{Ca}^{2+}$ reabsorption is voltage dependentthat is, it is exchanged with sodium ions ${ }^{14}$ whereas another part is parathyroid hormone sensitive and requires cAMP. ${ }^{14}$ The latter mechanism is highly dependent on mitochondrial ATP production and is therefore also sensitive to hypoxic and histotoxic hypoxia. The latter is caused by inhibitors of cytochrome oxidase, such as hydrogen sulphide and cyanide anions or formic acid. ${ }^{15}$ In workers occupationally exposed to formic acid the calciuria is directly related to the urinary formic acid concentration. ${ }^{16}$ The $\mathrm{K}_{\mathrm{i}}$ of the formic acid for the inhibition of the cytochrome oxidase is $1 \mathrm{mM}$ which agrees well with measured urinary formic acid concentrations. Higher concentrations could also lead to structural damage, ${ }^{17}$ and because the kidneys are highly dependent on oxygen under normal conditions urinary 
calcium determinations could probably be developed as a market for the dysfunction of the distal tubule.

Another function highly dependent on ATP is proton translocation. The enzyme is an ATPase as purified from bovine kidney. ${ }^{18}$ Protons excreted in the lumen are reabsorbed unless they are retained there because of reasons of electric neutrality or if they are combined with bases. This can take place with ammonia in the tubular cells, for example, forming ammonium ion which is excreted. ${ }^{19}$ The excretion of ammonium ions is inversely related to the renal potassium status ${ }^{20}$ and increased in chronic metabolic acidosis. ${ }^{21}$ Ammonia is derived from glutamine in a glutaminase catalysed reaction ${ }^{22}$ and the interorgan glutamine transport in metabolic acidosis is greatly enhanced. ${ }^{23}$

Urinary ammonia determinations are simple with a direct reading reflectometer, and worth while in the elucidation of the renal acidification capacity. ${ }^{24}$ Taking the formic acid example again, it seems that renal ammoniagenesis is impaired at relatively low levels of formic acid $^{16}$ or other histotoxic agents. ${ }^{25}$

\section{Glycosaminoglycans}

The glomerular basement membrane forms a sieve that prevents the filtration of proteins of molecular weight at least greater than 68000 daltons. ${ }^{26}$ This is partly achieved by the negative net charge of the macromolecular surface which repels other negatively charged molecules or cells such as erythrocytes. ${ }^{27}$ The basement membrane of the glomeruli consists mainly of heparan sulphate. ${ }^{28}$

The brush border lining of the tubular cell is also covered by glycosaminoglycans which contain little heparan sulphate. Immunisation against heparan sulphate causes glomerular injury ${ }^{28}$ whereas the interstitium is relatively spared. ${ }^{29}$ It is most likely that the brush border macromolecules are mainly chondroitin 4,6 sulphate which are the predominant species in excreted urine. ${ }^{30}{ }^{31}$ Glycosaminoglycan excretion and the frequency of microscopic haematuria are known to be increased by extended exposure to organic solvents. $^{32}$ Qualitative analysis will tell whether heparan sulphate excretion is specifically augmented thus pointing also to gromerular damage. ${ }^{31}$

H SAVOLAINEN

Institute of Occupational Health Sciences,

University of Lausanne,

Rue du Bugnon 19,

CH-1005 Lausanne,

Switzerland.

\section{References}

1 Phillips SC, Petrone RL, Hemstreet GP. A review of the nonneoplastic kidney effects of hydrocarbon exposure in human Occupational Medicine: State of the Art Reviews 1988; 495-509.

2 Roxe DM, Krumlovsky FA. Toxic interstitial nephropathy fror metals, metabolites and radiation. Seminars in Nephrolog $\overline{s p}$ 1988;8:72-81.

3 Walker RJ, Duggin GG. Drug nephrotoxicity. Annual Review of Pharmacology and Toxicology 1988;28:331-45.

4 Levin ML. Patterns of tubulo-interstitial damage associated with. nonsteroidal antiinflammatory drugs. Seminars in Nephrolog $P$ 1988;8:55-61.

5 Mujais S, Batlle DC. Functional correlates of tubulo-interstitiadu damage. Seminars in Nephrology 1988;8:94-9.

6 Kotchen TA, Welch WJ, Lorenz JN, Ott CE. Renal tubulap chloride and renin release. $J$ Lab Clin Med 1987;110:533-40.

7 Brody IA. Myotonia induced by monocarboxylic aromatic acids: possible mechanism. Arch Neurol 1973;28:243-6.

8 Koschier FJ, Acara M. Transport of 2,4,5-trichlorophenoxy. acetate in the isolated, perfused rat kidney. $J$ Pharmacol Ex/S Ther 1979;208:287-93.

9 Manninen A, Kangas J, Klen T, Savolainen H. Exposure of Finnish farm workers to phenoxy acid herbicides. Arch Environ Contam Toxicol 1986;15:107-11.

10 Jones DIR, Knight AG, Smith AJ. Attempted suicide witk herbicide containing MCPA. Arch Environ Health 1967;18 363-6.

11 Johnson HRM, Koumides O. A further case of MCPA poisoning $\overrightarrow{0}$ Br Med J 1965;ii:677-8.

12 Kancir CB, Andersen C, Olesen AS. Marked hypocalcemia in a fatal poisoning with chlorinated phenoxy acid derivatives. $C l i 5$ Toxicol 1988;26:257-64.

13 Need AG, Guerin MD, Pain RW, Hartley TF, Nordin BEC. Th tubular maximum for calcium reabsorption: normal range an correction for sodium excretion. Clin Chim Acta 1985;1509 87-93.

14 Friedman PA. Basal and hormone-activated calcium absorptio in mouse renal thick ascending limbs. Am J Physiol 1988\% 254:F62-70.

15 Erecinska M, Wilson DF. Inhibitors of cytochrome $c$ oxidase Pharmacol Ther 1980;8:1-20.

16 Liesivuori J, Savolainen $\mathrm{H}$. Effect of renal formic acid excretion on urinary calcium and ammonia concentration. Klin Wochensch 1987;65:860-3

17 Zitting A, Savolainen H, Nickels J. Biochemical and toxicologicat effects of single and repeated exposures to polyacetal ther modegradation products. Environ Res 1982;29:287-96.

18 Gluck S, Caldwell J. Proton-translocating ATPase from bovin@ kidney medulla: Partial purification and reconstitution. $\mathrm{Am}$ 叉 Physiol 1988;254:F71-9.

19 Silbernagel S, Scheller D. Formation and excretion of $\mathrm{NH}_{3} \longleftrightarrow \mathrm{NH}_{4}{ }^{+}$. New aspects of an old problem. Klip Wochenschr 1986;64:862-70.

20 Good DW. Effects of potassium on ammonia transport bo medullary thick ascending limb of the rat. $J$ Clin Invesen 1987;80:1358-65.

21 Brosnan JT, Lowry M, Vinay P, Gougoux A, Halperin ML. Renå ammonium production-une vue canadienne. Can J Physid Pharmacol 1987;65:489-98.

22 Golden MHN, Jahoor P, Jackson AA. Glutamine production rate and its contribution to urinary ammonia in normal man. Clff Sci 1982;62:299-305.

23 Welbourne TC. Interorgan glutamine flow in metabolic acidosis Am J Physiol 1987;253:F1069-76.

24 Ratnaike RN, Buttery JE, Hoffmann S. Blood ammonio measurement using a simple reflectometer. $\mathrm{J}$ Clin Chem Clip Biochem 1984;22:105-8. 
25 Preuss HG, Areas J, Schubert P, Lenhart M, Slemmer D. Role of renal oxygen consumption rate in the adaptive ammoniagenesis of acidosis. In: Kovacevic Z, Guder WG, eds. Molecular nephrology. Biochemical aspects of kidney function. Berlin: Walter de Gruyter, 1987:263-8.

26 Abrahamson DR. Structure and development of the glomerular capillary wall and basement membrane. Am J Physiol 1987; 253:F783-94.

27 Barsotti P, Albedi FM, Fabrizi E, Marinozzi V. Ultrastructural localization of sulphate glycoconjugates in the human capillary wall using the high iron diamine method. J Submicr Cytol Pathol 1988;20:549-56.

28 Abrass CK, Cohen AH. Characterization of renal injury initiated by immunization of rats with heparan sulfate. Am J Pathol 1988;130:103-11.
29 Bruijn JA. Hogendoorn PCW, Hoedemaker PJ, Fleuren GJ. The extracellular matrix in pathology. J Lab Clin Med 1988; 111:140-9.

30 Palo J, Savolainen H. Studies on serum and urinary glycopeptides and glycosaminoglycans in aspartylglucosaminuria. Clin Chim Acta 1972;36:431-7.

31 Wlad H, Fenrych W, Lacka K, Sikorska-Horst W. Urinary glycosaminoglycans in patients with hypothyroidism and healthy subjects. J Clin Chem Clin Biochem 1988;26:259-64.

32 Hotz P, Pilliod J, Soderstrom D, Rey F, Boillat M-A, Savolainen $H$. Relationship between renal function tests and a retrospective organic solvent exposure score. Br J Ind Med (in press).

\section{Correspondence and editorials}

The British Journal of Industrial Medicine welcomes correspondence relating to any of the material appearing in the journal. Results from preliminary or small scale studies may also be published in the correspondence column if this seems appropriate. Letters should be not more than $\mathbf{5 0 0}$ words in length and contain a minimum of references. Tables and figures should be kept to an absolute minimum. Letters are accepted on the understanding that they may be subject to editorial revision and shortening.

The journal now also publishes editorials which are normally specially commissioned. The Editor welcomes suggestions regarding suitable topics; those wishing to submit an editorial, however, should do so only after discussion with the Editor. 